\title{
Entrepreneurial Brinkmanship: Lessons Learned from Best Buy and FedEx
}

\author{
James C Wetherbe (Texas Tech University)
}

\author{
KEYWORDS: Wholesale Trade, Retail Trade, \\ Entrepreneurship, Innovation, Management, \\ Negotiation, Leadership, Strategy, Learn From Leaders.
}

Entrepreneurial startups have the advantage of nimbleness that comes from being small and collaborative. They are a speedboat compared to the corporate barges they compete against in the early stages of market development. However, as a successful startup grows, the advantage of nimbleness erodes. Inevitable growing pains set in and the startup must overcome them to reach the next level.

In some cases, the next stage of growth requires "going big" - e.g., moving from a regional to a national presence or rapidly expanding distribution capabilities. For these startups, the choice truly is between going big or going out of business. Usually a midway position isn't defensible against much bigger players that enjoy huge economies of scale or other advantages. In these cases, startup management must often play the game of brinkmanship, pushing events to near disaster to achieve an advantageous outcome.

The perseverance needed to be a successful entrepreneur is daunting. FedEx had one of the most courageous, against-the-odds launches in corporate history: creating an airline-based mail and package distribution service under the nose of the two goliaths (the U.S. Postal Service and United Parcel Service). In the early 1970s, when then-Federal Express was created, it was the largest venture capital startup in history. Imagine the discouragement on March 12, 1973, when the company's first attempt at launching a national overnight delivery system yielded only six packages-one a birthday present from founder Fred Smith for an associate.

Fred Smith, like so many entrepreneurs, had to endure the numerous "I-told-you-so" skeptics.

But this article is not about starting up. It is about when entrepreneurial initiatives succeed, and future success requires the founding entrepreneur to take the company to the brink-and make "bet the company" moves in order to survive. It is during this time when leaders must combine the art of brinkmanship with entrepreneurship.

This article provides illuminating and instructive examples of brinkmanship at Best Buy and FedEx in their formative years, and highlights the inspirational leadership and perseverance by Best Buy founder Dick Schulze and FedEx founder Fred Smith. Their examples are particularly meaningful since the companies have survived long after the brinkmanship events discussed in this article, as well as many more that followed.

\section{Best Buy Brinkmanship with Suppliers for Big Box Stores}

Founded by Schultze in 1966, Best Buy today is a $\$ 50$ billion multinational consumer electronics enterprise with 180,000 employees. Originally named Sound of Music, Best Buy had one of its key episodes of brinkmanship in 1983 at the Consumer Electronics Show in Las Vegas.

By then, Sound of Music was becoming obsolete, along with every other mom-and-pop shop and regional operator. National chains led by Circuit City were replacing them or swallowing them up. Sound of Music, at the time a regional chain of nine small stores, would have to go big or go home.

Schulze believed he had to think big: literally, building stores that were three times the size of existing stores, and spreading them across the country. Though the times were threatening and discouraging to most small consumer electronic store operators, Schulze was enthusiastic about a new superstore concept that would capitalize on emerging and exciting new consumer electronics categories. With this strategy, he aspired to transform Sound of Music from a $\$ 10$ million a year 
operation to a $\$ 50$ million enterprise. Schulze could never have imagined that the $\$ 50$ billion revenue mark was actually in his future.

But to pull it off, Schulze and his leadership team of Brad Anderson and Kurt Reedy would have to convince suppliers to support the plan with more inventory and credit. That would be no easy feat.

They arrived for the Consumer Electronics Conference in Las Vegas with two folders, one containing Plan A and the other Plan B. Plan A was admittedly a smokeand-mirrors vision of a new concept store and a picture of a location. Plan B was the alternative that Elliot Kaplan -- Schulze's longtime friend, board member and attorney -- had insisted he take to ensure that after 17 years Schulze would not lose his house if Plan A failed. Plan B was a dreaded bankruptcy plan that was not only an alternative but leverage.

Schulze was ready for brinkmanship.

\section{No Help from Media Rumor}

But Schulze wasn't ready for a bogus news story. While he was at the Las Vegas conference a bizarre, rumorbased story appeared in the conference newspaper, the CES Daily. The story claimed Sound of Music was closing its doors forever. Though not true, it would not help Schulze's negotiations with suppliers for his new vision.

Livid but energized, Schulze met with suppliers for a few intense days. He had to expose his vulnerability since his current, aging business model was stretched to the point where liquidity and equity was gone. This of course reinforced the story in CES Daily. The telltale look of concern was apparent on supplier's faces. "Was the news story about Sound of Music true?"

Schulze acknowledged these were challenging times. But he followed with the good news: Plan A. It revealed his vision for new stores with the new name of Best Buy. These big box stores would be 25,000 square feet and expand to offer the full spectrum of consumer electronics, including computers, cameras, camcorders, VCRs and appliances. In so doing, the demographic would expand from young males to a wider audience -including females, who account for $50 \%$ of consumer purchases.

\section{Tornado Tutorial}

What were the origins of Schulze's new bold concept?

We gain wisdom from how we respond to the trials and tribulations of entrepreneurship and life. Such was the case with a rare tornado that hit the Twin Cities and literally ripped the roof off of the Sound of Music store in nearby Roseville. Whatever inventory wasn't destroyed by the tornado was exposed to the rainstorm that followed. It was a great lesson in teamwork and leadership as employees from all stores rallied to salvage what they could from further damage and relocate it to a warehouse in Bloomington, Minnesota.

But now what? They had insurance for damaged merchandise but no insurance for business continuity. Could they survive? In a stroke of entrepreneurial genius, Schulze knew people were curious about looking at tornado damage and also loved deep discounts. So he put up tents; brought in salvaged merchandise and added all returned, open box items from the warehouse; and had a tent sale at the very site of the destroyed Roseville store. It was a megasuccess, with consumer excitement like Schulze had never witnessed before. Cars lined up for blocks.

They quickly began to run out of merchandise, so they brought in merchandise from other stores and discounted it to keep the sale going.

This experience provided Schulze with a key insight that would lead to a competitive advantage for Best Buy. Historically, consumer electronics stores had used a small display room staffed with professional, commissioned sales personnel dressed in business attire. Inventory was kept "in the back" in an adjacent warehouse much larger than the display room. It usually took more than 10 steps to make a purchase because retrieving inventory from the warehouse was a timeconsuming and inconvenient process.

At the tent sale, all the inventory was brought out and ready for customers to take it to checkout with assistance from casually attired sales staff. This greatly reduced time, increased convenience and made the customers feel less intimidated by the staff. This was the genesis of the future Best Buy format: having all inventory on the sales floor, with non-commissioned iconic "blue-shirt" staff to assist but not pressure customers.

The new Best Buy would change pricing strategy from matching competitors' prices to offering deep discounts. 
Like so many innovators, Schulze and his team discovered the power of huge inventory and deep discounts as a result of a disaster, in this case a tornado. For a lesser leader it could have been a business-ending disaster. Without that leadership, Schulze and Sound of Music would be just another footnote in consumer electronics history.

\section{Brinkmanship and the Leverage of Plan B}

So the defining moment had arrived in Las Vegas. Could Schulze get the suppliers to believe in his new, innovative vision for Best Buy?

The skepticism was inevitable from supplier CEOs, national sales managers, but most often from credit managers:

"You do not have the capital for this initiative."

"How are you going to fund this?"

"You already owe us money."

The only financial rebuttal Schulze could make was that he had a $\$ 100,000$ line of credit using his home as collateral, which was not enough. Don't miss that after 17 years of running a successful, thriving business Schulze still had to mortgage his home like a new entrepreneur to get to the next level. Though it was not enough to fund his new venture, such a bold move demonstrates that an entrepreneur believes in himself and his business. But after that, negotiation becomes pivotal.

Schulze explained that he needed suppliers to extend credit terms and ship product to the new store.

A composite response from suppliers was, "You are asking us to give you more time on payment on future purchases when you haven't even paid us what you owe today. This is a lot to ask." Then came the apparent brush off: "We will let you know."

Enter plan B: bankruptcy. Schulze pulled out the folder and explained that without supplier cooperation, he would have no choice but to file by the end of the week and liquidate. In that scenario suppliers would get pennies on the dollar.

Schulze boldly took it to the brink by saying, "Either you're going to have to trust us, or we're going to have to file for bankruptcy. If you trust us, I won't promise exactly when you'll get paid but I promise that you will. Everything we owe you now, plus everything we will owe you on the basis of future purchases."

With the credibility of having always paid his bills for the past 17 years, Schulze achieved the win/win he needed from suppliers by offering a lose/lose alternative no one wanted.

The rest is history -- a history with more brinkmanship bumps ahead that would not have been possible if Schulze had not practiced brinkmanship with his entrepreneurship.

\section{FedEx Brinkmanship by Changing the Rules}

When Fred Smith was a student at Yale, he shared his vision of using Memphis (his home town) as an airline hub to deliver overnight packages all over the country. His idea would lead to a $\$ 45$ billion global courier employing 300,000 and headquartered in Memphis.

Smith's economics professor at the time did not grasp the vision. In fact he disparagingly wrote on Smith's paper that it was an interesting idea but that it didn't sound economically feasible. In this professor's class, such ideas did not receive a grade higher than $\mathrm{C}$.

That didn't discourage Smith; he would become an entrepreneur willing to apply the art of brinkmanship to dysfunctional Federal regulations. He named his new venture "Federal Express" and launched it in 1971.

Despite initial challenges, by the mid-1970s Federal Express was a booming success, with phenomenal growth that was exceeding the capacity of the small fleet of 32 Falcon jets. It was not uncommon for two of the small jets to fly "wingtip-to-wingtip" between the more dense supply lanes to fulfill a shipment delivery. In addition, the company's cargo was shifting from shipping documents to finished and unfinished inventory -- boxes carrying parts, electronics and other bigger, heavier products that required more cargo space. Multiple aircraft flying to the same destination was a highly inefficient problem, and solving it required larger aircraft.

To operate larger aircraft, Federal Express needed authorization from the Civil Aeronautics Board (CAB) to 
accommodate existing and future demand-and needed it fast. But when the company filed for an exemption to operate five used DC-9 aircraft with greater capacity, virtually every major U.S. airline carrier filed an opposition to the grant. Why? They also shipped cargo. With great reluctance, the CAB issued an order denying Federal Express's request. Its rationale: though public demand justified an exception, the agency did not have the statutory authority to grant exceptions under the regulatory regime established by Congress.

\section{The First Rule is to Change the Rules}

Smith concluded that the only way to gain federal approval would be to remove air cargo service from the current regulatory structure. Early in 1976, he initiated a full-court press to persuade Congress to eliminate regulations that were constraining public demand for air cargo services.

The company's first attempt was a limited-amendment initiative that would allow $\mathrm{CAB}$ to permit Federal Express and other carriers to operate larger aircraft. But the airlines and the Teamsters Union vigorously opposed it, and it failed.

Undaunted, Smith began an all-out effort to take the issue to the brink at Congress' next session in 1977.

\section{Using the Media in Brinkmanship}

As he launched a media campaign to get the public on his side, Smith corralled every reporter who would listen and fought for appearances before Congressional committees.

Smith's tactics were in sharp contrast to the automotive industry, which at the time was campaigning for government regulations for protection from competition from imports. Smith wanted the government to allow competition and get out of the way.

In an effort to outsmart the government attorneys, Smith was furiously studying and becoming an expert in aviation law while the deregulation hearings were underway. After listening to a young counsel to the House Aviation Subcommittee argue in favor of creating obstacles for Federal Express, Smith realized that the attorney lacked the expertise to know what he was talkiing about.

In a defining moment of brinkmanship, Smith pulled out a copy of the Federal Aviation Act of 1958. He held it in the young attorney's face and said, "You don't know anything about this act!" Smith grasped the 250-page book and ripped it in half, threw it on the table and said, "This is what I think of your arguments!" He had a flare for generating publicity.

Smith kept his public relations campaign focused on members of Congress, the press, the business community, and astutely at Federal Express customers, whom he showered with a brochure called, "Sometimes Free Enterprise Needs a Little Help."

\section{Politics as Usual}

Even with all that effort, politics as usual intervened. An amendment that would have got the job done was approved by the Senate 73-0 but was defeated nonetheless in the House. It became entangled between Representative Glenn Anderson of California and Senator Howard Cannon, chairman of the Aviation Subcommittee. Federal Express's amendment became collateral damage.

But Smith refused to quit. To continue the campaign, he rented a house in Washington to provide lodging for him and his team of Federal Express employees and attorneys.

On the bright side, newly elected President Jimmy Carter had committed to eliminating bureaucratic barriers to progress, some of which were relevant to Smith's objectives. But powerful interests headed by the commercial airlines were fighting against it.

It was during this era that I recall being on a crosscountry Boeing 747 flight with fewer than 20 passengers on board. I asked the flight attendant why her airline would schedule a flight that obviously had little customer demand. She explained there was a whole lot more money to be made from the cargo being shipped in the belly of the plane than from passengers. I began to connect the dots between regulations and Federal Express.

But Smith's ongoing effort achieved the needed public crescendo, and Federal Express finally got the break it needed. Congressman Anderson, who had previously undermined what was known as the Federal Express Relief Bill, became an unexpected ally. He backed a bill that would allow open-entry licensing to all air cargo carriers. It was amended and passed. Just like that, as 
can happen in politics, the battle was over. Federal Express had won. But the real winners were the customers who increasingly needed to get more products delivered overnight.

Smith shouted at the news, "We are free to fly!"

\section{When it Makes Sense to Help Your Competitors}

Ironically, there was a third beneficiary to Fred Smith's brinkmanship: Federal Express competitors. They, too, would benefit mightily from the deregulation of cargo delivery.

Why would Federal Express want to do that? The real question is, when does it make sense to change the rules of your industry? The answer is, only when the changes will benefit your customers, your organization and possibly some of your competitors. A key to the success of Smith's effort was that it was not viewed as self-serving, as evidenced by public support. And of course public support can be crucial when you are taking the government to the brink.

As with Best Buy, the rest of the Federal Express story is history. More brinkmanship bumps in the road would come, but to a more experienced leadership team. Federal Express officially changed its name to "FedEx" in 1994, making its informal abbreviation its official name. Today it's the industry leader in air cargo transportation.

\section{Lessons Learned}

These two examples of brinkmanship by two legendary entrepreneurs are instructive. Interestingly enough, their separate initiatives eventually even collide. How? When we fast forward, we see it was because of Smith's pursuit of fast, reliable overnight delivery that Internet entrepreneur stories such as Amazon.com and many others dot-coms were possible. We also see brick-andmortar retailers, including Best Buy, having to face a new episode of brinkmanship spurred by online retailing as customers benefited from new choices afforded by "brick vs. click."

Some retailing giants have responded well to this challenge and others have not. Best Buy was challenged and endured stock prices dropping $75 \%$ before rebounding from another episode of brinkmanship and entrepreneurship.
Here are four lessons from these stories:

\section{Envision New Possibilities and Opportunities}

First, just as with the original entrepreneurial idea, taking an organization to the next level requires vision for that which does not yet exist. In the case of Best Buy, it was creating a new exciting big box shopping experience, forged from lessons learned from the tornado sale, to create a more customer-centric experience with lower operating costs than the competition (e.g., Circuit City).

In the case of FedEx, it was about obtaining government approval to acquire larger aircraft. Then FedEx could provide overnight replenishment that helped customers reduce inventory and the associated carrying cost (i.e., in many cases overnight delivery eliminates the need to stock inventory).

Grasping a new vision can seem obvious in hindsight, but is easily missed before. Consider that in the 1960s the entire computer mainframe industry roster was characterized as Snow White (IBM) and the seven dwarfs (Univac, RCA, Honeywell, Burroughs, NCR, $\mathrm{CDC}$ and GE). These companies were so busy fighting one another that they totally missed the mini-computer revolution introduced by new entrepreneurial efforts from Digital Equipment, Data General and Hewlett Packard in the early 1970 s.

The architecture of online computing was transforming behind the distracted "Disney characters"' backs. Instead of using a computer system one at a time, it became about using "systems of computers" in distributed networks. This new architecture would eventually lead to the Internet.

But school was not over with the mini-computer tutorial. New lessons awaited. When the next computer industry innovation wave occurred with micro (PC) computers, it was companies like Apple, Microsoft, Dell and Compaq that were leading the way. It was the same for cell phones.

And this phenomenon is not unique to the high-tech industry. For example, why were Folgers and Maxwell House so blindsided by Starbucks? How did they miss the opportunity to raise the bar in consumer taste for coffee? 


\section{Be Customer-Centric}

As we learned from Best Buy and FedEx, new visions must include the customer.

It is tempting to take an organization to the next level in a way that is anti-competition and self-serving rather than customer-centric. But that can be a monumental mistake. Brinkmanship is challenging enough without customer support and, even worse, can invite unwanted government intervention (e.g., the IBM and Microsoft anti-trust actions). Consider how critical customer support and public opinion was to FedEx's brinkmanship.

In contrast to unwanted government intervention, we've seen embarrassing cases of "wanting" government intervention for protection that is not customer-centric. For example, consider the U.S. auto industry's 1970 campaigns for protection from international competition. The companies sought protection because their products were of inferior quality (which was well documented in various consumer studies). The inroads the Japanese automakers were making were putting the U.S. auto industry on the brink.

Schulze and Smith's visions were customer-centric. Schulze wanted to provide an exciting, bigger and better shopping experience for the customer that included lower prices. Smith wanted to expand his capacity to ship more and larger inventory, which would benefit FedEx customers.

Placing customers first provides moral high ground, which strengthens an entrepreneur's stance when engaging in entrepreneurial brinkmanship. Customerfirst approaches may also help your competitors, as was the case when FedEx lobbied to change federal regulations. Other couriers benefited. But is it not better to be perceived as a customer-driven industry leader than as a follower?

\section{Have Courage and Perseverance}

As the stories of Schulze and Smith explain, courage and perseverance are required for entrepreneurial brinkmanship. The "failure is not an option" mindset of continuing to explore new alternatives to secure an advantageous outcome is often necessary.

The backgrounds of these two icons, who achieved so much when they were just young men, are so different that it is noteworthy that they have such similar abilities to achieve what others would consider unachievable.

Schulze grew up in a middle-income family; a bicycle paper route in St. Paul was his first job. When he needed to buy his first car, he revealed his entrepreneurial instincts. Going outside to get a newspaper in the winter months can be a bitter experience in Minnesota. Starting in November, Dick decided he would better serve his customers if he got off his bike and placed newspapers behind storm doors on the front porch. Better-served customers could mean better Christmas tips. It worked. Schulze made enough money to pay cash for his first car.

Smith, on the other hand, had the advantage of a lucrative family trust afforded by his father's entrepreneurial efforts, which included the Toddle House restaurant chain and Dixie Greyhound Lines. Unlike Schulze, Smith could have lived on his trust fund after being sent off to Yale for an exclusive Ivy League education.

Different backgrounds -- yet both chose similar, challenging paths. With courage and perseverance, these two men were willing to risk it all and take it to the brink when necessary.

\section{Strive to Inspire as a Leader}

In leadership, an ounce of inspiration is worth a pound of control.

Too often employees feel over-managed and under-led, over-controlled and under-inspired. Relationships with employers can be "transactional," where a leader only meets a basic commitment to administer pay, privileges and perks in exchange for employees' time, skills, effort and cooperation.

A leading factor for those who become entrepreneurs is a burning desire to be their own boss. Escaping uninspiring jobs and working for others is worth the risk and effort for these leaders.

Does anyone question that entrepreneurs work longer and harder for themselves than they would for a manager with whom the feel little connection?

To succeed at entrepreneurship and the occasional necessary episode of brinkmanship, entrepreneurs need to be inspirational and transformational leaders. They raise employees' awareness of consequential issues and influence them to transcend their own self- 
interests for the good of the team or organization. They draw their employees into something bigger than themselves. In so doing, they inspire them to work harder and sacrifice more than they ever expected they would.

\section{Schulze and Smith: Convincing Examples}

After the tornado destroyed Schulze's Roseville store in Minnesota, the remaining undamaged inventory would soon be ruined by the post-tornado rain. His leadership team of Brad Anderson and David Telschow desperately needed help, and fast. All employees were called; within two hours all of them showed up. They dropped what they were doing and drove through the rain prepared to do whatever it took. The impact of the tornado put the company in poor financial shape but this experience proved how much everyone cared about the organization and its leadership. Employees who dropped everything to help experienced the feeling of being part of something bigger than themselves.

Like Schulze, Smith knows people have to be highly valued to be inspired. When they are, they respond in kind. At the end of one pay period in the difficult early days of FedEx, employees received a memo along with their paychecks. The memo, from Smith, stated that they were welcome to cash their checks, but he suggested it sure would be helpful if some of them waited just a few days.

Can you imagine? In how many companies would such a memo cause employees to stampede to the bank for fear of their checks bouncing? Or start looking for another job? Surprisingly, that is not what happened. Indeed, it was startling how many employees honored the humble request. To this day, some of those checks remain uncashed. Their owners display them proudly, as a badge of honor, in frames on their office walls.

I share these two stories with my students. I then tell them, I wish that they someday join such organizations that might become the next Best Buy or FedEx. Or better yet, start their own company and enjoy the personal and professional rewards that come from being part of something bigger than themselves.

\section{Conclusion}

The stories of Dick Schulze and Fred Smith illustrate well that entrepreneurship is about providing customer value in a way that previously did not exist. Taking organizations to the next level requires ongoing brinkmanship, where the stage gets bigger and the stakes get higher.

New technology and innovations create possibilities that can challenge and replace the visions that were successful yesterday. It has been said that "success breeds failure" -- that success can prevent entrepreneurs from seeking or even seeing new opportunities. To combat this behavior, Smith is well known for this familiar greeting to colleagues at FedEx:

Smith: "How's it going?"

Employee: "Great."

Smith: "Well don't get used to it. We'll have to keep changing to remain competitive."

This type of mindset is fertile for new visions; and new visions often require entrepreneurial brinkmanship. A superior chance of success is possible when customers are included in that vision, and when employees are led by inspirational and transformational leaders.

\section{References}

Schulze, Dick, Becoming the Best: A Journey of Passion Purpose, and Perseverance, Idea Platforms, Cambridge, MA, 2011.

Trimble, Vance, Overnight Success: Federal Express \& Fred Smith, its Renegade Creator, Crown Publishing, New York, 1993.

Wetherbe, James, The World on Time: The Eleven Management Principles that made FedEx an Overnight Sensation, Knowledge Exchange, Santa Monica, CA 1997.

Additional Search Terms: Fred Smith, Dick Schulze, Richard M. Schulze, FedEx history, BestBuy history, financing, capital investment, venture capital, investors 